\title{
Expedient in situ test techniques for predictive maintenance of rendered façades
}

Received (in revised form): 3oth June, 2006

\section{Inês Flores-Colen}

is a PhD student and research assistant at IST, with a research grant from FCT and an MSc in construction from IST. Her research is related to the inspection and maintenance of façades of current buildings and in situ tests. She is a member of CIB W60 and president of the DECivil IST CIB Student Chapter.

\section{Jorge de Brito}

graduated in civil engineering and received his masters and doctoral degrees at IST-Technical University of Lisbon, Portugal, where he is an associate professor. He is a member of IABSE, FIB, $\mathrm{CIB}$ and IABMAS, as well as several reputed national engineering societies. He is a member of several national committees under CEN as well as the following working groups: CIB W80/RILEM 100-TSL - Service Life Prediction of Building Materials and Components; CIB W86 - Building Pathology; and CIB TG39 - Deconstruction. His research work deals with deterioration, rehabilitation and management of concrete structures. He co-authored the Handbook of Concrete Bridge Management, published by ASCE Press in 2004.

\section{Vasco Peixoto de Freitas}

is a full professor of construction at FEUP-Porto University, Portugal, where he is head of the Construction Physics Laboratory, head of the Masters in Rehabilitation of Built Heritage and head of the Construction Institute. He has authored or co-authored around 100 scientific and didactic publications concerning hygrothermic behaviour, pathology and rehabilitation of buildings. He is a consultant in the following fields: hygrothermic behaviour of buildings and pathology and rehabilitation of buildings.
Abstract
The practice of predictive maintenance (through periodic inspections) depends on the efficiency of in situ evaluations of the in-service performance of the constructive solutions, which in turn depends on a set of logical procedures inherent to a performance- based methodology and a correct diagnosis.
In situ tests are a precious auxiliary tool for visual inspections, since they allow the detection of gross diagnosis mistakes, reduce the subjectivity of visual inspections and enable a more accurate assessment of the real maintenance needs. These tests have limitations, however, and depend on the technique used (often the limited precision of a technique only allows a qualitative analysis) and the experience of the practitioners. In situ tests for rendered façades include a variety of tests and techniques, most of them not standardised, and therefore a coherent and global classification is sometimes difficult to establish.
In this paper a methodology for choosing the most adequate in situ techniques to diagnose in-service performance of rendered façades is proposed. The subjects of this analysis were current and expedient techniques, used in several inspections performed in

Jorge de Brito

Department of Civil Engineering and Architecture

Section of Construction IST-Technical University of Lisbon Av. Rovisco Pais, 1049-001 Lisbon Portugal

Tel: +351218419709

Fax: +351218497650

E-mail: jb@civil.ist.utl.pt 
different renders, within the PhD research work of the first author. These techniques are classified and also characterised in terms of the data collected (parameters measured), their contribution to understanding in-service performance (analysis of relevant properties), the degradation state (anomalies and their causes) and their relation to maintenance needs. Finally, they are compared and rated using various criteria and evaluated in terms of their adequacy for in situ assessment.

\section{Keywords:}

in situ tests, predictive maintenance, façades, rendering, expedient techniques

\section{INTRODUCTION}

Maintenance is becoming increasingly more decisive for buildings' management and an important contribution to global expenses throughout their life cycle. For example, for an undertaking with a service life of 50 years, expenses related to the design and execution stages represent around 20-25 per cent of global costs, while the service and maintenance stage is responsible for 75-80 per cent of these costs (Perret, 1995).

Maintenance is defined in ISO 15686-1 (ISO, 2000) as a combination of all the technical and administrative actions that allow the building and its elements to perform during its service life the functions they were designed for. There are various ways of approaching buildings' maintenance depending on knowledge of the behaviour of the component to be studied:

- Preventive maintenance (often termed planned maintenance): the items included in this category are those works which are planned to take place at predefined, regular intervals in order to keep the component in good performance (Riley and Cotgrave, 2005); this type of maintenance reduces the number of non-planned works and allows the estimation of overall costs.

- Predictive maintenance (or conditioned-based maintenance) by performing inspection planning: the predictions involved in this type of maintenance show an important capacity for growth in accuracy (Palmer, 1999); for some time it has been a useful tool for reducing life cycle costs and finding more efficient ways of using maintenance budgets (Hertlein, 1999); it is an appropriate maintenance strategy for elements whose condition and performance can be suitably monitored (Morcous and Lounis, 2005).

- Reactive maintenance: associated with the correction of unexpected anomalies, almost always of an urgent nature, leading to unavoidable extra costs; thus, it is important to standardise technical procedures that allow the minimisation of the drawbacks of this type of maintenance (Flores, 2002).

The preventive and predictive maintenance strategies can be integrated in proactive maintenance, preventing problems before they occur 
(Palmer, 1999) and minimising cost throughout a building's service life. Therefore, the performance of periodic inspections during the service stage (predictive maintenance) increases the capacity to detect ('when' and 'where') the need for interventions, reducing the number of unforeseen anomalies (Flores-Colen and de Brito, 2004) and allowing a growing knowledge of the in-service behaviour of construction elements, their residual service life and premature degradation agents (BCIS, 2001).

In this context, the practice of predictive maintenance depends on the efficiency of in situ assessment of the in-service performance of the various construction elements, which must account for a set of logical procedures inherent both to a performance-based methodology, to be implemented after the design stage, and to a correct diagnosis at the service stage.

For façade rendering, the performance-based methodology includes the definition and quantification (by the designers, backed by the manufacturers) of the rendering properties relevant to proper in-service performance, taking into account the functions they must fulfil to ensure a good performance of the façades: watertightness and protection of the walls, finishing of the surfaces, durability faced with the outer actions, and adequacy to use (Veiga, 2005). A correct diagnosis must define the problem, collect the available data, characterise the existing anomalies and their probable causes, evaluate the in-service performance (fulfilment of the functions established at design), check whether the users' demands are being fulfilled and, finally, define the corrective, preventive or monitoring actions. In Figure 1, a methodology is proposed to support rendered façade diagnosis and to choose intervention strategies, based on various other existing methodologies (referred to in Flores-Colen et al., 2006), related to service life estimation, diagnosis improvement (through observation and in situ techniques) and backing criteria for the selection of maintenance actions.

In situ assessment of in-service performance is a complex activity, usually restricted to a visual appraisal of an element's degradation, which may lead to a deficient diagnosis and consequent performance of inadequate interventions. The usual absence of records of intervention (historic to the building) aggravates this situation through an accumulation of errors. The main reasons justifying the complexity of this type of assessment can be identified as follows.

- Design solutions are prescriptive and not performance-based by nature.

- Technical data provided by manufacturers most of the time is insufficient (or descriptive by nature); even when the minimum requirements of EN998-1 are specified, properties stated are not enough to evaluate the global behaviour of outer rendering (Veiga, 2005).

- In situ inspections are mostly visual and only rarely are other auxiliary diagnosis techniques (in situ or in laboratory) used.

- Most of the buildings do not possess access means, thus limiting the inspection to the ground floor, causing the need for auxiliary means of access or entering the building. 


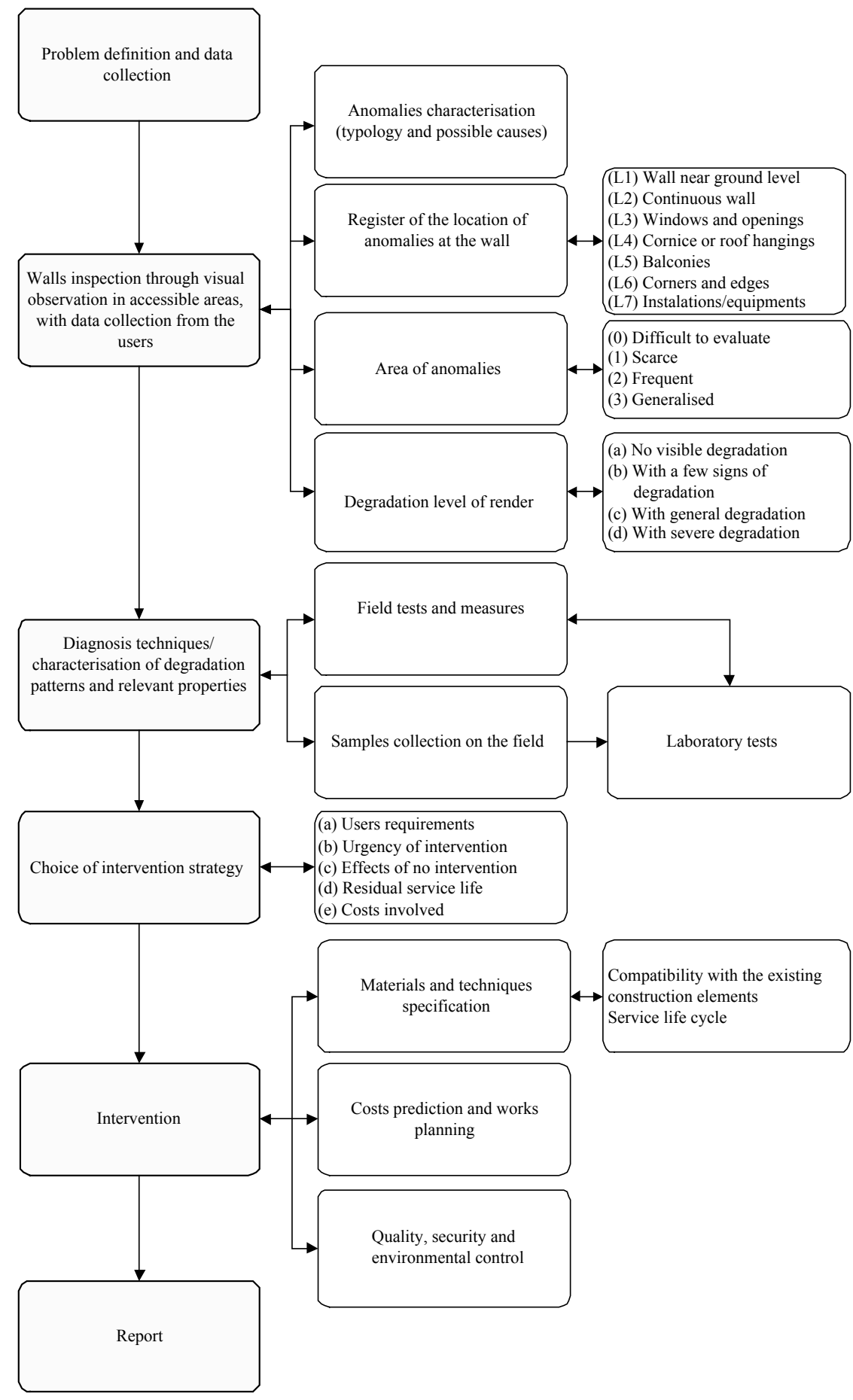

Figure 1: Flowchart of a diagnosis methodology for rendered façades, adapted from Flores-Colen et al., 2005

- Insufficient available data (eg outdated final drawings and ignorance of both the characteristics of materials applied and previous interventions). 


\section{IN SITU TEST TECHNIQUES FOR INSPECTION SUPPORT}

\section{Inspections and in situ test techniques}

The frequency of inspections during the service life of buildings differs in various countries and is related to several factors (economic, cultural and social, among others). For example, Bureau Veritas (Bureau Veritas, 1993) recommends localised inspections every three to five years to check anomalies and in-service performance, and global inspections every 10 to 15 years to examine eventual functional liabilities and factual ageing of all the elements. BS 8210 (BSI, 1986) recommends systematic inspections as follows:

- Continuous, regular observation by the building user as part of the occupancy of the building;

- Annual visual inspection of the main elements under supervision of suitably qualified personnel;

- Full inspection of the building fabric by suitably qualified personnel at least every five years.

In Portugal, legislation about to be approved (General Code for Edifications, RGE) refers that current periodic inspections must be performed every 15 months after issue of the dwelling licence and that they are intended to detect anomalies and originate the actions listed in the building's Manual of Inspection and Maintenance (MIME). Buildings without a MIME must be subjected to an expert inspection at least once every eight years.

Inspections normally occur through visual observation of the building's elements. They allow the qualitative characterisation of anomalies, the evaluation of their eventual causes and the assessment of in-service conditions, complementing the documentation obtained previously (claims report, design elements and inspection reports, among others). In situ tests are a precious auxiliary tool for visual inspections and allow a more accurate characterisation of:

- Existing degradation mechanisms of the walls (eg staining, efflorescence, dampness and cracking);

- Changes of the rendering properties directly related to its performance (eg mechanical strength and water absorption coefficient);

- In situ conditions (eg environmental parameters);

- Type of materials applied, by laboratory testing specimens collected in situ (eg characterising the mortar formulation and its binder content).

Therefore, carrying out these tests reduces the subjectivity of visual inspections (which are very dependent on the background and experience of the inspector) and assesses with greater precision the real maintenance needs. Testing also allows the detection of small changes that may be associated with pre-pathology symptoms (phenomena preceding easily detectable anomalies) (Flores, 2002; Calejo, 1996). 
These tests have several shortcomings, however, possibly leading to an increase in the inspection duration and to results that are confusing and hard to interpret (especially when available data concerning the materials applied are scarce or nil). They have limitations and, depending on the technique used, the limited precision only allows a qualitative analysis.

According to ISO 15686-2 (ISO, 2001):

\begin{abstract}
'Standardized techniques are usually recommended just because they are standardized. However, apart from generally being phenomenological and very simple (too simple in certain cases), many of the standardized inspection techniques suffer from the fact that they rely upon subjective judgements of the practitioners. This makes comparisons between studies from different practitioners less reliable, which in fact counteracts the purpose of standardization. Accordingly, there is a need for further development in this field and the standardization of existing, more sophisticated techniques.
\end{abstract}

Currently, there are only a few (usually expensive) in situ test techniques that allow reliable data of a quantitative nature about any degradation level (Branco and de Brito, 2005). Nevertheless, the combined use of various techniques facilitates the interpretation of the results and minimises the limitations referred. Therefore, even with some shortcomings, these tests allow the detection of gross diagnosis mistakes (Silva, 2004) and, in some cases, spare the use of laboratory analyses (time-consuming and increasing the inspection's costs) (Branco and de Brito, 2005). It is also preferable to use them in conjunction with visual observation instead of relying solely on the latter.

\title{
CLASSIFICATION AND CHARACTERISATION OF EXPEDIENT IN SITU TECHNIQUES
}

In situ tests include a variety of techniques associated with the determination of various characteristics, raising some difficulties in putting together a coherent and global classification (Branco and de Brito, 2005). There are different classifications for in situ test techniques. According to the literature (Branco and de Brito, 2005; Silva, 2004; Campanella, 2003), they may be classified in terms of the:

- degree of destruction caused in the surfaces they are applied to (destructive, semi-destructive and non-destructive);

- existence or non-existence of an artificial intervention (passive, also named non-invasive, and active, also named invasive);

- principle they are based on (mechanical, electrical, magnetic, electromagnetic, ultrasonic, radioactive, sensorial, thermic, chemical, electrochemical, among others);

- type of results obtained (properties to be evaluated);

- type of technology used (low or high-tech);

- main objectives (eg strength, durability and geometry);

- elements they are applied to (eg cladding, background or both);

- activities where they intervene (eg quality control, building inspection, code conformity check-up, among others). 
The adequate choice of technique is very important since it significantly influences the costs and time schedule involved, the type of equipment to carry in situ, the data to collect, the know-how needed, the type of human resources (number of people involved and their technical background) and the activities needed before (eg acquisition of the temporary means of access) and after (eg repairs to restore the initial conditions) the test.

To facilitate the choice of the best in situ technique to assess the in-service performance of renderings in outer walls a methodology is proposed based on the experience acquired in inspections of building façades, within the $\mathrm{PhD}$ research work of the first author, and a specialised technical bibliography (on existing procedures).

The techniques that are subject to analysis in this paper (Table 1) are current techniques to support inspection (Hollis and Gibson, 1991) used in several inspections performed in different renders: pull-off (T1)

(RILEM, 2004), pendulum hammer (T2) (RILEM, 1997), MartinetBaronie device (T3) (RILEM, 1982), ultrasounds (T4) (ASTM, 2002a), infrared thermometer (T5), infrared radiation pyrometer (T6),

Table I: Identification of the expedite in situ test techniques under analysis

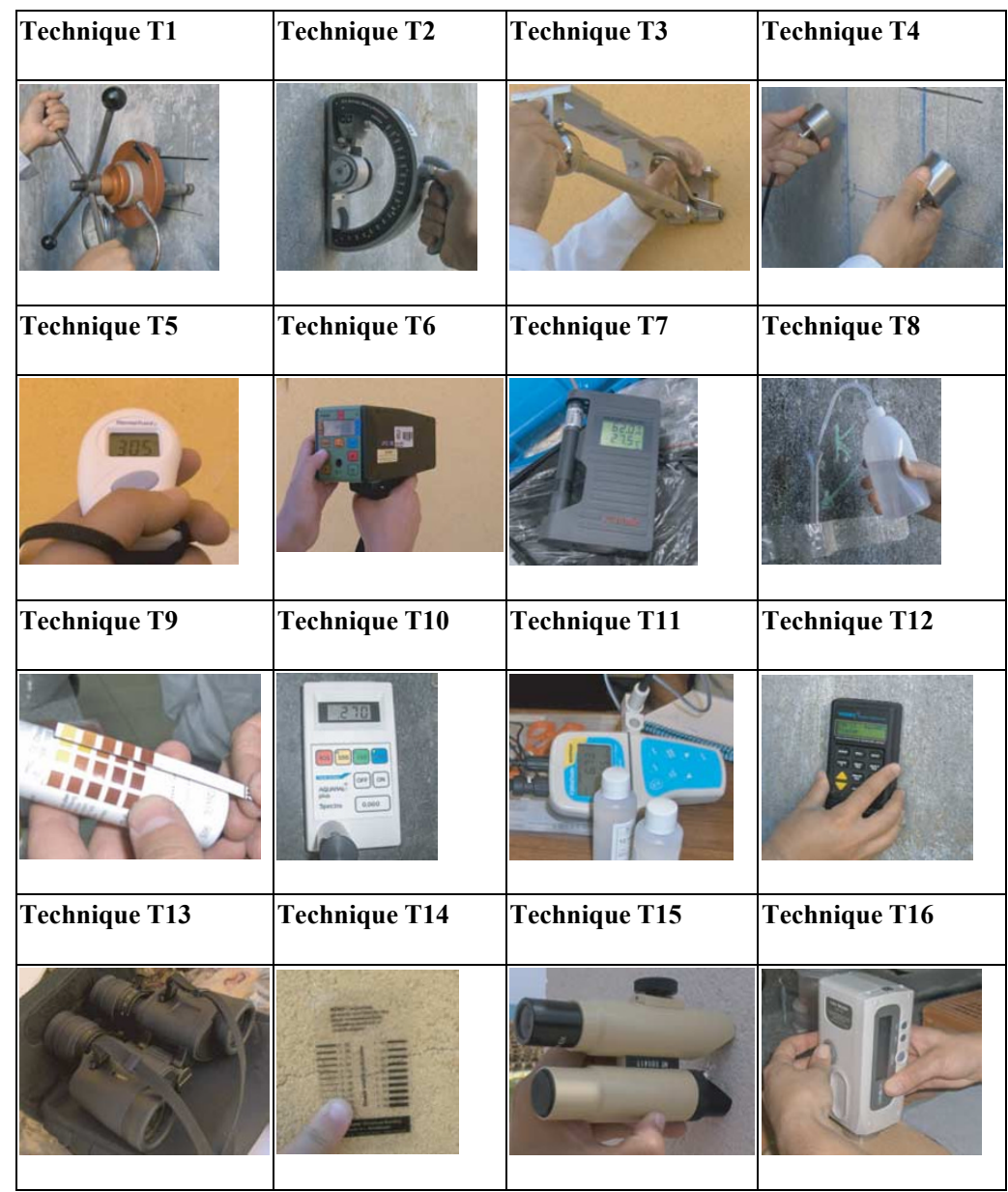


thermohygrometer (T7), Karsten tube (T8) (RILEM, 1980), colorimetric strips (T9), field kit (T10), $\mathrm{pH} /$ conductivity/overall salt content measurement (T11), humidimeter (T12), binoculars (T13), cracks gauge (T14), optical microscope (T15) and colorimeter (T16) (ASTM, 2002b).

The previous techniques were divided according to the principle they are based on and then characterised in terms of data collected (measured parameters), their contribution to understanding the in-service performance (in terms of the properties that may be analysed with the technique), the anomalies and their relationship with the maintenance needs. The flowcharts presented in Figures $2-5$ systemise the previous data.

The characterisation of each technique using flowcharts allowed the conclusion that these techniques can help in the diagnosis of current anomalies in rendered façades: cracking, loss of adherence, loss of cohesion, staining, dirt, biological colonisation and efflorescence, among others. Generally these techniques did not provide a direct correlation with the performance requirements for rendering considered in EN 998 (CEN, 2003) or other technical documents (see Table 2); most of these criteria result from laboratory tests. The pull-off technique ( $\mathrm{T} 1$ - determination of the adherence tension to the background) is the only one of those analysed that allows a direct correlation with the minimum requirements of EN 998 (see Figure 2).

Maintenance needs therefore can be identified in a qualitative manner. In order to improve the diagnosis during inspections and in-service performance assessment, additional requirements must be defined for

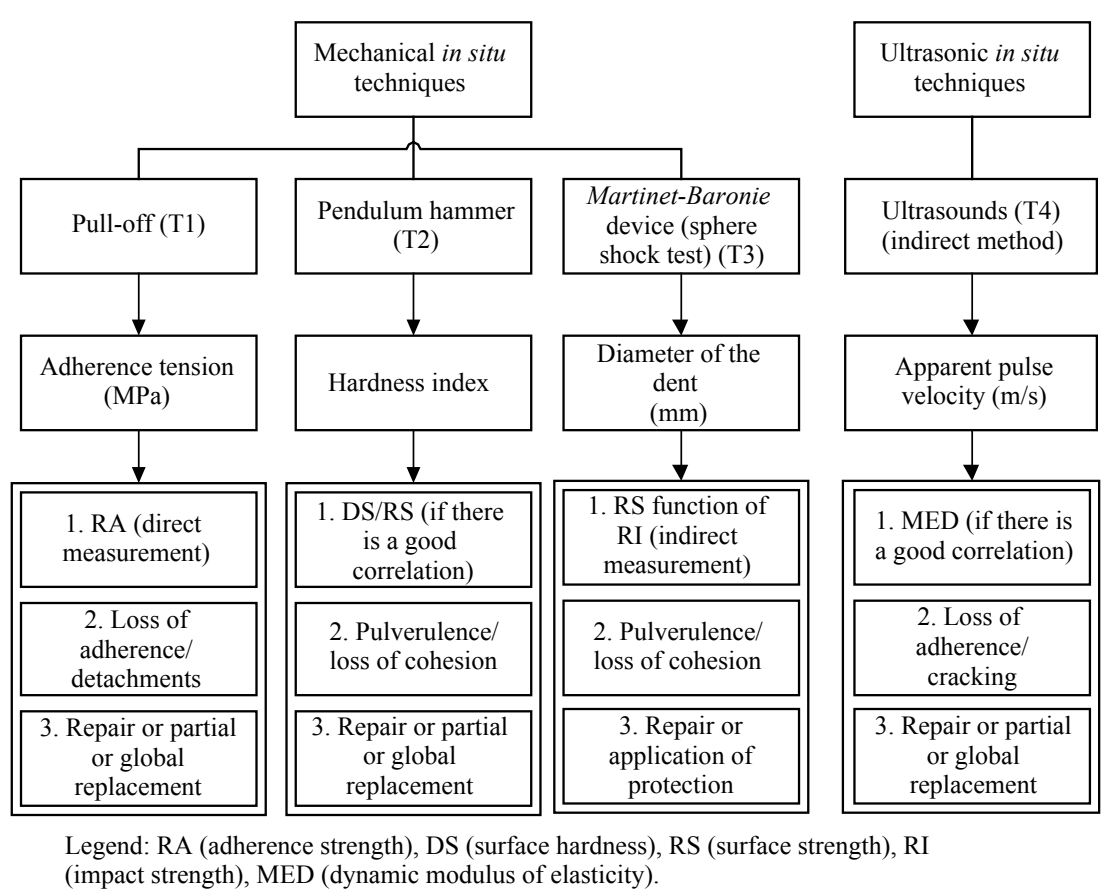

Figure 2: Mechanical and ultrasonic techniques for rendered façades - measured parameters, performance properties, type of anomalies and eventual maintenance needs 


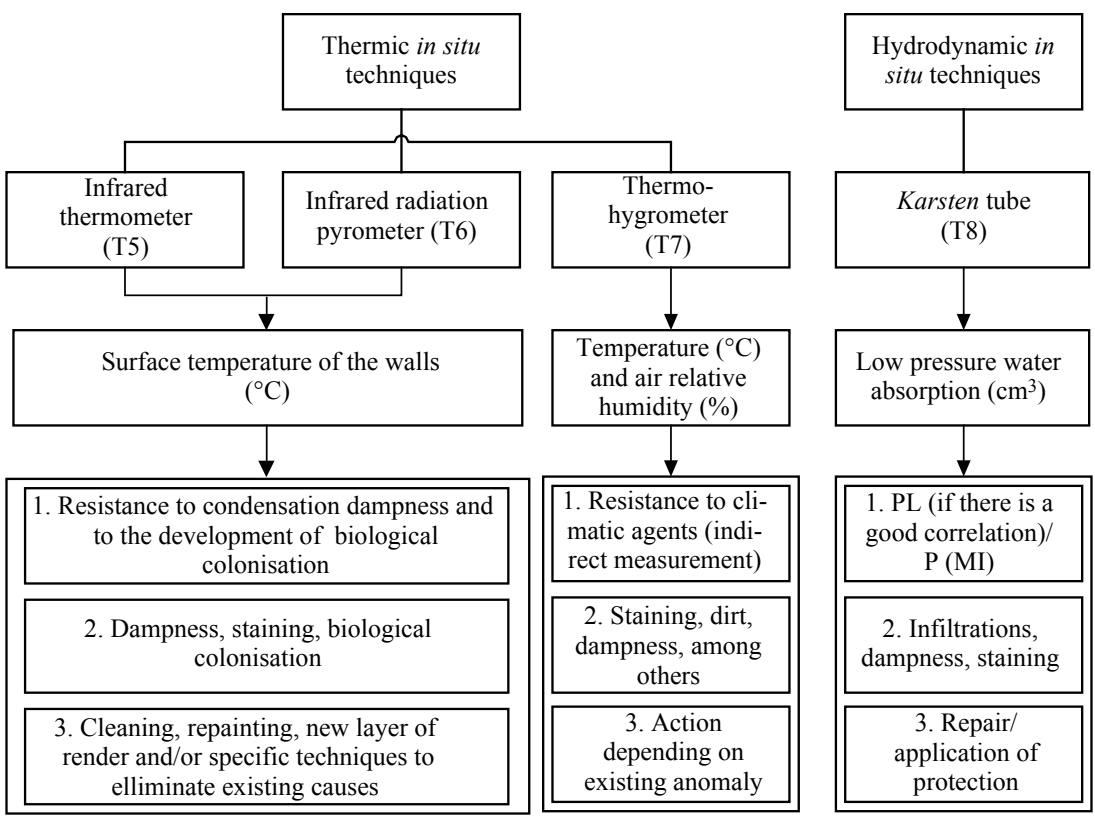

Legend: PL (water permeability), P (MI) (indirect and qualitative measurement of porosity).

Figure 3: Thermic and hydrodynamic techniques for rendered façades - measured parameters, performance properties, type of anomalies and eventual maintenance needs

these expedient techniques which must be correlated with performance requirements mentioned in standards, complementing the existing procedures (eg RILEM or ASTM documents). This aspect is still the subject of on-going research.

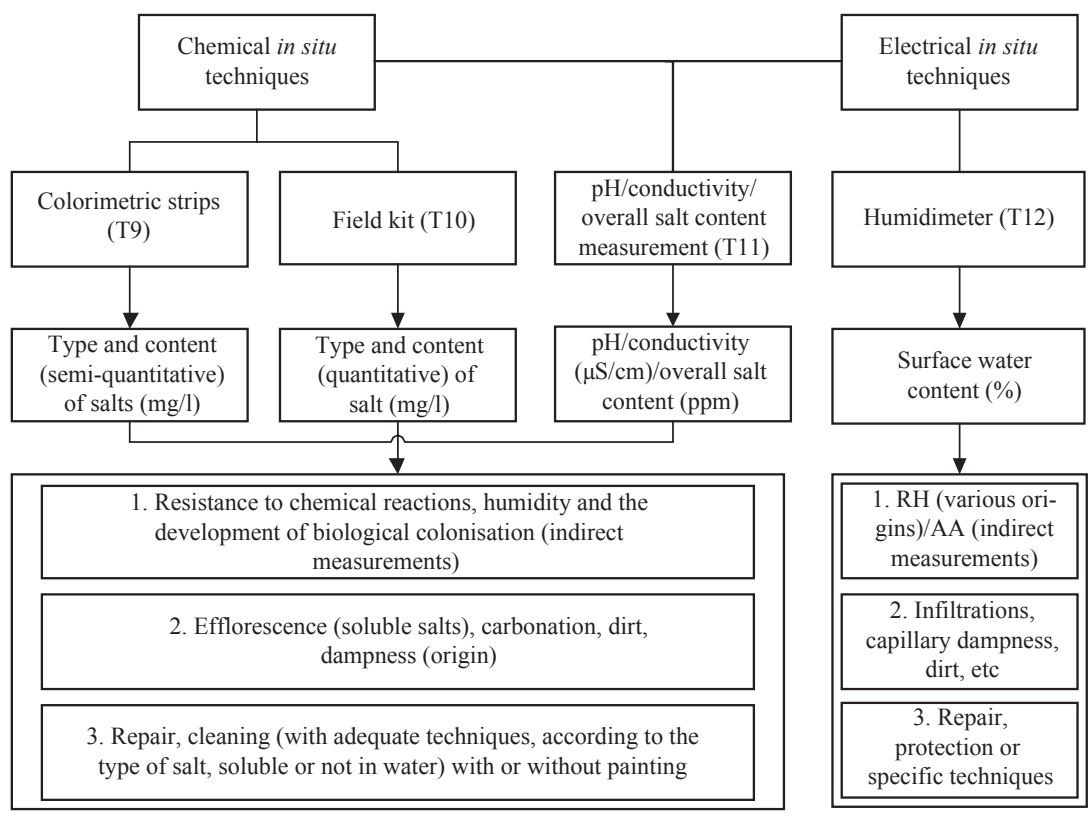

Legend: RH (resistance to humidity), AA (water absorption).

Figure 4: Chemical and electrical techniques for rendered façades — measured parameters, performance properties, type of anomalies and eventual maintenance needs 


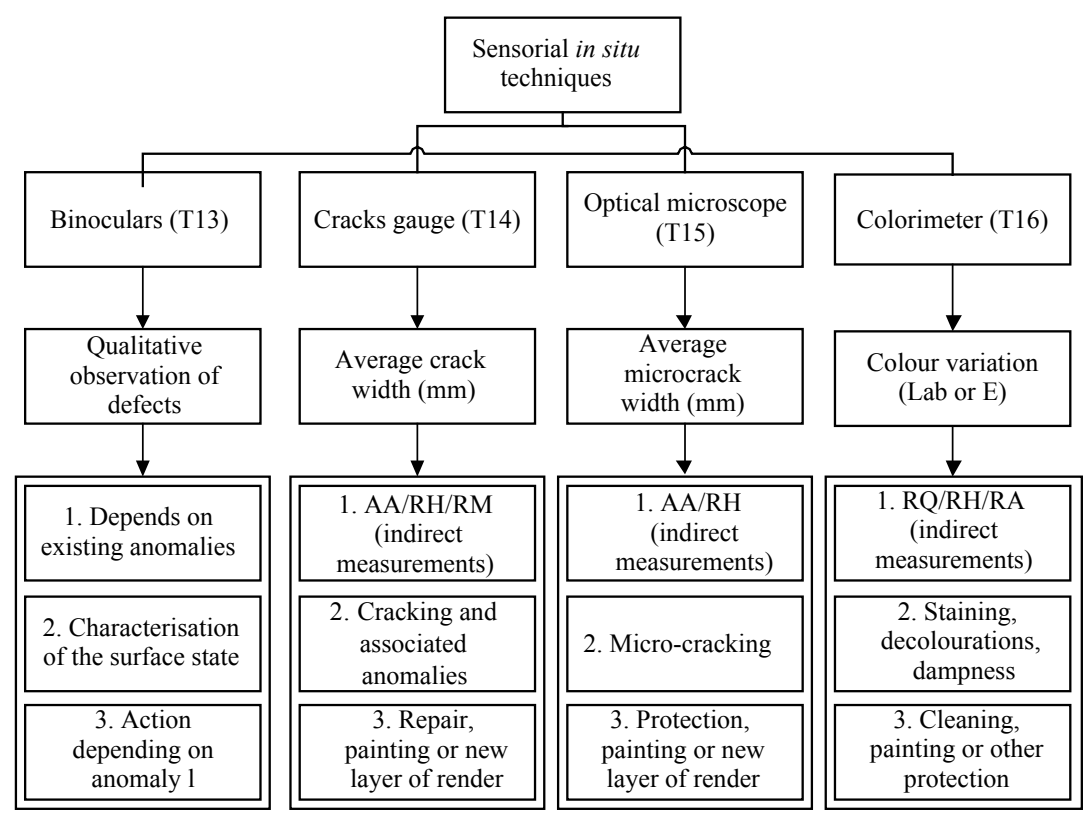

Legend: AA (water absorption), RH (resistance to humidity), RM (mechanical strength), $\mathrm{RQ}$ (resistance to chemical reactions), RA (resistance to climatic actions).

Figure 5: Sensorial (including optics) techniques for rendered façades - measured parameters, performance properties, type of anomalies and eventual maintenance needs

\section{COMPARISON OF EXPEDIENT IN SITU TEST TECHNIQUES}

The comparison of the various techniques must take into account their adequacy for in situ assessment to be performed in each case. Accordingly, the techniques mentioned above were compared based on criteria already defined in previous studies for in situ techniques applied to concrete bridges (Branco and de Brito, 2005) and to the diagnosis of staining of rendered walls (Flores-Colen et al., 2006).

In Table 3 limits for each criterion are proposed to clarify the comparative analysis and facilitate the choice between techniques (the ones within this analysis or others that may be used in the future); the following weights are considered (Branco and de Brito, 2005): $\mathrm{P}=2$ (the technique fulfils the criterion), $\mathrm{P}=1$ (the technique does not fully comply) and $\mathrm{P}=0$ (no compliance with the criterion).

The adequacy coefficient for each technique was obtained through the sum of the various criteria according to equation 1 (the bigger the sum the more adequate the technique to be used in situ):

Coefficient $_{\text {adequacy }}=\mathrm{A}+\mathrm{B}+\mathrm{C}+\mathrm{D}+\mathrm{E}+\mathrm{F}+\mathrm{G}+\mathrm{H}+\mathrm{I}+\mathrm{J}+\mathrm{K}$

where:
A: low equipment acquisition costs
B: easy and swift use of the equipment
C: significant volume of useful data 
Table 2: Hardened rendering properties, acceptance criteria and methods of assessment from literature review (Flores-Colen et al, 2005)

\begin{tabular}{|c|c|c|c|}
\hline Properties & $\begin{array}{l}\text { Specification and } \\
\text { acceptance criteria }\end{array}$ & $\begin{array}{l}\text { Specifications } \\
\text { Doc. reference }\end{array}$ & $\begin{array}{l}\text { Tests methods } \\
\text { Doc. reference }\end{array}$ \\
\hline $\begin{array}{l}\text { Compressive } \\
\text { strength }\left(R_{c}\right)\end{array}$ & $\begin{array}{l}\text { Categories: } C S I\left(R_{c}=0.4 \text { to } 2.5\right. \\
\left.\mathrm{N} / \mathrm{mm}^{2}\right) \text {, CSII }\left(R_{c}=1.5 \text { to }\right. \\
\left.5 \mathrm{~N} / \mathrm{mm}^{2}\right), C S I I I \\
\left(R_{c}=3.5 \text { to } 7.5 \mathrm{~N} / \mathrm{mm}^{2}\right) \\
\operatorname{CSIV~}\left(R_{c} \geq 6 \mathrm{~N} / \mathrm{mm}^{2}\right)\end{array}$ & EN 998-I & $\begin{array}{l}\text { EN I0I5-II } \\
\text { EN I96-I }\end{array}$ \\
\hline Flexural strength $\left(R_{f}\right)$ & $\begin{array}{l}\mathrm{R}_{\mathrm{f}} \geq 1.5 \text { to } 2 \mathrm{~N} / \mathrm{mm}^{2} \\
\text { (wall with high } \\
\text { exposure to impact loads) }\end{array}$ & $\begin{array}{l}\text { Cahiers } 2413 \\
240 \text { I } \\
\text { LNEC 289/95 }\end{array}$ & $\begin{array}{l}\text { Cahier } 2669-4 \\
\text { EN I96-I } \\
\text { DIN I8555 } \\
\text { EN I0I5-II }\end{array}$ \\
\hline $\begin{array}{l}\text { Capillary water } \\
\text { absorption (C) }\end{array}$ & $\begin{array}{l}\text { Categories: WI to } W 2 \\
C \leq 0.4 \text { or } \leq 0.2 \mathrm{~kg} / \mathrm{m}^{2} \cdot \mathrm{min}^{0.5} \\
\mathrm{C} \leq 2 \text { to } 4 \mathrm{~g} / \mathrm{dm}^{2} \cdot \mathrm{min}^{0.5} \\
\mathrm{C}=1 \text { to } 2.5 \text { or } \\
<\mathrm{I} .5 \mathrm{~g} / \mathrm{dm}^{2} \cdot \mathrm{min}^{0.5} \text { (wall } \\
\text { with high exposure to rain) }\end{array}$ & $\begin{array}{l}\text { EN 998-I } \\
\text { Cahiers 240I, } \\
2477,2413\end{array}$ & $\begin{array}{l}\text { EN I0I5-18 } \\
\text { Cahier 2669-4 } \\
\text { NF BI0-502 }\end{array}$ \\
\hline $\begin{array}{l}\text { Water permeability } \\
\left(W_{P}\right)\end{array}$ & $\leq \mathrm{I} \mathrm{ml} / \mathrm{cm}^{2}$ after $48 \mathrm{~h}$ & $\begin{array}{l}\text { EN 998-I } \\
\text { CSTB (1992) } \\
\text { Cahier 240I }\end{array}$ & EN I0I5-2| \\
\hline \multirow[t]{2}{*}{$\begin{array}{l}\text { Dynamic elastic } \\
\text { modulus }\left(E_{d}\right)\end{array}$} & $\begin{array}{l}E_{d} \leq 7500 \text { to } 14000 \mathrm{~N} / \mathrm{mm}^{2} \\
E_{d} \geq 5000 \text { to } 10000 \mathrm{~N} / \mathrm{mm}^{2} \\
\text { (wall with high exposure to } \\
\text { impact loads) }\end{array}$ & $\begin{array}{l}\text { Cahiers } 2401 \\
2413,2477\end{array}$ & Cahier 2669-4 \\
\hline & $\mathrm{E}_{\mathrm{d}} \leq 10000 \mathrm{~N} / \mathrm{mm}^{2}$ & LNEC 289/95 & $\begin{array}{l}\text { Cahier 2669-4 } \\
\text { NF BI0-502 }\end{array}$ \\
\hline $\begin{array}{l}\text { Stresses induced by } \\
\text { shrinkage (restrained) }\end{array}$ & $\begin{array}{l}\text { Classification (cracking } \\
\text { susceptibility): little } \\
(S \geq I \text { and } R \geq I \text { ) or } \\
\text { medium }(S \geq I \text { and } \\
0.6 \leq R<I), \text { where } S \\
\text { (safety coefficient to } \\
\text { the opening of the first } \\
\text { crack), } R(\text { resistance } \\
\text { coefficient to cracking } \\
\text { evolution) }\end{array}$ & Veiga (1997) & $\begin{array}{l}\text { Veiga (I997) } \\
\text { DIN } 52450\end{array}$ \\
\hline \multirow[t]{2}{*}{$\begin{array}{l}\text { Water vapour } \\
\text { permeability }\end{array}$} & $\begin{array}{l}\text { Water vapour permeability } \\
\text { coefficient } \mu \leq \text { declared } \\
\text { value }\end{array}$ & $\begin{array}{l}\text { EN 998-I } \\
\text { Cahier 240I }\end{array}$ & EN $1015-19$ \\
\hline & $\begin{array}{l}\text { Thickness of air layer of } \\
\text { equivalent diffusion } \\
\text { to } 0.1 \mathrm{~m} \text { of render } \\
S_{d} \geq 0.15 \mathrm{~m}\end{array}$ & LNEC 289/95 & DIN I8555-Part I \\
\hline Adhesion on substrates & $\begin{array}{l}\geq 0.3 \mathrm{MPa} \text { or cohesive } \\
\text { fracture pattern (at least } \\
\text { in } 80 \% \text { of the area) }\end{array}$ & $\begin{array}{l}\text { EN 998-I } \\
\text { CSTB (1992) } \\
\text { Cahier 240I }\end{array}$ & $\begin{array}{l}\text { EN } 1015-12 \\
\text { LNEC 289/95 }\end{array}$ \\
\hline Durability & $\begin{array}{l}\text { No visible degradation } \\
\text { after weathering cycles } \\
\text { tests, checking compatibility } \\
\text { of one coat rendering with } \\
\text { substrates (adhesion and } \\
\text { water permeability) }\end{array}$ & $\begin{array}{l}\text { LNEC } 289 / 95 \\
\text { EN } 998-I\end{array}$ & EN $10|5-2|$ \\
\hline
\end{tabular}

D: easy interpretation of the results

E: none or little degree of destruction

F: portable equipment

G: no energy source needed in situ

$\mathrm{H}$ : no need for specialised workmanship or technicians with specific training

I: reliable results 
Table 3: Description of the values adopted for each criterion

\begin{tabular}{|c|c|c|c|}
\hline \multirow[t]{2}{*}{ Criterion } & \multicolumn{3}{|c|}{ Description of the values adopted } \\
\hline & 2 & 1 & $\mathbf{0}$ \\
\hline A & if $A \leq 500 €$ & if $500 €<A \leq 2500 €$ & if $A>2500 €$ \\
\hline B & $\begin{array}{l}\text { if it is easy and swift } \\
\text { to use, i.e. maximum } \\
\text { duration of up to I } \mathrm{h}\end{array}$ & $\begin{array}{l}\text { if it does not } \\
\text { comply with one of } \\
\text { the conditions }\end{array}$ & $\begin{array}{l}\text { if it does not } \\
\text { comply with any of } \\
\text { the conditions }\end{array}$ \\
\hline C & $\begin{array}{l}\text { if it provides data } \\
\text { on performance and } \\
\text { degradation }\end{array}$ & $\begin{array}{l}\text { if data provided is } \\
\text { limited to one of } \\
\text { the fields mentioned }\end{array}$ & $\begin{array}{l}\text { if data is very } \\
\text { often insufficient } \\
\text { on both } \\
\text { fields mentioned }\end{array}$ \\
\hline $\mathrm{D}$ & $\begin{array}{l}\text { if measurements made } \\
\text { are rapid to analyze }\end{array}$ & $\begin{array}{l}\text { if measurements } \\
\text { require some } \\
\text { time to analyze }\end{array}$ & $\begin{array}{l}\text { if measurements } \\
\text { made need } \\
\text { other tests for a } \\
\text { better interpretation }\end{array}$ \\
\hline$E$ & $\begin{array}{l}\text { non-destructive } \\
\text { technique }\end{array}$ & $\begin{array}{l}\text { semi-destructive } \\
\text { technique needing slight } \\
\text { repair afterwards }\end{array}$ & $\begin{array}{l}\text { destructive technique } \\
\text { needing repair }\end{array}$ \\
\hline $\mathrm{F}$ & $\begin{array}{l}\text { equipment easy to carry, } \\
\text { both in terms of } \\
\text { dimension and mass }\end{array}$ & $\begin{array}{l}\text { if it does not comply } \\
\text { with one of the } \\
\text { conditions }\end{array}$ & $\begin{array}{l}\text { if it does not } \\
\text { comply with any of } \\
\text { the conditions }\end{array}$ \\
\hline G & $\begin{array}{l}\text { if it does not need } \\
\text { energy or is self-sufficient }\end{array}$ & $\begin{array}{l}\text { if it needs an } \\
\text { energy source in situ }\end{array}$ & $\begin{array}{l}\text { if it does not } \\
\text { comply with the } \\
\text { criterion }\end{array}$ \\
\hline $\mathrm{H}$ & $\begin{array}{l}\text { if there is no } \\
\text { need for specific training } \\
\text { of any of the } \\
\text { inspectors }\end{array}$ & $\begin{array}{l}\text { if at least one } \\
\text { of the inspectors needs } \\
\text { specific training }\end{array}$ & $\begin{array}{l}\text { if it does not } \\
\text { comply with the } \\
\text { criterion }\end{array}$ \\
\hline I & quantitative analysis & qualitative analysis & $\begin{array}{l}\text { analysis depending } \\
\text { on other } \\
\text { results }\end{array}$ \\
\hline J & $\begin{array}{l}\text { if it fully complies } \\
\text { with the criterion }\end{array}$ & $\begin{array}{l}\text { if in some cases } \\
\text { it requires the collection } \\
\text { of in situ specimens } \\
\text { for laboratorial } \\
\text { tests }\end{array}$ & $\begin{array}{l}\text { if collecting in situ } \\
\text { specimens is always } \\
\text { mandatory }\end{array}$ \\
\hline K & $\begin{array}{l}\text { if it fully complies } \\
\text { with the criterion }\end{array}$ & $\begin{array}{l}\text { if means of access } \\
\text { are needed but they } \\
\text { are relatively easy to } \\
\text { carry to the site }\end{array}$ & $\begin{array}{l}\text { if it does not } \\
\text { comply with any of } \\
\text { the conditions }\end{array}$ \\
\hline
\end{tabular}

J: no laboratory work needed

$\mathrm{K}$ : no means of access needed

Finally, the expedient in situ test techniques identified in Table 1 are compared in Table 4 taking into account the adequacy factors obtained through the use of the values for each criterion (Table 3). These criteria analyse the techniques as well as the additional works before, during and after the test.

Table 4 leads to the conclusion that most techniques under analysis show a good adequacy for in situ assessment and are rapid to use (expedient techniques). Generally, however, they do not allow a direct assessment of the performance (criterion $\mathrm{C}$ in Tables 3 and 4), are more prone to the characterisation of degradation and depend in excess on auxiliary means of access. The pull-off technique has the lowest adequacy factor (10 out of a possible 22) due to the low values of factors B (the preparation procedures, the time to cure the resin, the test execution and the repairs can take more than one day), E (high degree of destruction), 
Table 4: Comparison between in situ test techniques (list non-exhaustive) applied to outer rendering, using weight factors and determining the adequacy to in situ assessment of the techniques

\begin{tabular}{|c|c|c|c|c|c|c|c|c|c|c|c|c|}
\hline \multirow{2}{*}{$\begin{array}{l}\text { In situ test } \\
\text { technique }\end{array}$} & \multicolumn{11}{|c|}{ Comparison criteria } & \multirow{2}{*}{$\begin{array}{l}\text { Adequacy } \\
\text { factor }\end{array}$} \\
\hline & A & B & C & D & $\mathbf{E}$ & $\mathbf{F}$ & G & H & I & J & K & \\
\hline TI & I & 0 & 2 & 2 & 0 & 0 & 0 & 1 & 2 & 2 & 0 & 10 \\
\hline T2 & I & 2 & 1 & 0 & 2 & 2 & 2 & 2 & 1 & 2 & I & 16 \\
\hline T3 & 0 & I & 2 & 2 & I & 1 & 2 & 2 & 2 & 2 & 0 & 15 \\
\hline T4 & 0 & 2 & I & 0 & 2 & 2 & I & 2 & 2 & 2 & I & 15 \\
\hline T5 & 2 & 2 & 0 & 2 & 2 & 2 & 2 & 2 & 0 & 2 & I & 17 \\
\hline T6 & I & 2 & 1 & 2 & 2 & 2 & 2 & 2 & 2 & 2 & I & 19 \\
\hline T7 & I & 2 & 0 & 2 & 2 & 2 & 2 & 2 & 2 & 2 & 2 & 19 \\
\hline T8 & 2 & 2 & I & 2 & 2 & 2 & 2 & 2 & I & 2 & I & 19 \\
\hline T9 & 2 & 2 & 1 & 2 & I & 2 & 2 & 2 & 1 & 1 & I & 17 \\
\hline TI0 & I & 1 & I & 2 & I & 2 & 2 & 2 & 2 & 1 & I & 16 \\
\hline TII & I & 2 & 1 & 2 & I & 2 & 2 & 2 & 2 & 1 & I & 17 \\
\hline TI2 & I & 2 & I & I & 2 & 2 & 2 & 2 & I & I & I & 16 \\
\hline T13 & 2 & 2 & I & 1 & 2 & 2 & 2 & 2 & 1 & 2 & 2 & 19 \\
\hline TI4 & 2 & 2 & I & 2 & 2 & 2 & 2 & 2 & 2 & 2 & I & 20 \\
\hline TI5 & I & 2 & 1 & 2 & 2 & 2 & 2 & 2 & 2 & 2 & I & 19 \\
\hline T16 & 0 & 2 & 2 & 2 & 2 & 2 & 2 & 2 & 2 & 2 & I & 19 \\
\hline
\end{tabular}

F (the equipment that was used is not easy to carry, even though there are other lighter pieces of equipment on the market), $\mathrm{G}$ (an energy source is necessary to create the test core) and $\mathrm{K}$ (means of access are necessary). This technique is nevertheless recommended especially for claddings instead of other more complex test techniques (not analysed within this study), because it allows a direct correlation with the minimum requirements of EN 998 (CEN, 2003).

Therefore, it is important that the inspector decides what is more relevant for the analysis in each case, knowing the limitations of the available techniques. The adequacy factors of these techniques, or of others not referred to in this paper, can be adapted by the inspector by modifying the weight of each criteria according to its importance to the analysis (eg in certain cases the absence of means of access to the building is very limiting to the choice of in situ techniques).

\section{CONCLUSIONS}

It is always better to perform in situ tests in conjunction with a visual inspection instead of resorting only to the visualisation of the problem. The simultaneous use of various test techniques facilitates the interpretation of the results and minimises some of the shortcomings of this type of test (confusing and hard-to-interpret results and subjective judgments by the inspectors).

In this paper a methodology to support the choice of various in situ test techniques was proposed, by analysing 16 expedient techniques currently used in the diagnosis of rendered façades: pull-off, pendulum hammer, Martinet-Baronie device, ultrasounds, infrared thermometer, infrared radiation pyrometer, thermohygrometer, Karsten tube, colorimetric strips, field kit, $\mathrm{pH} /$ conductivity/overall salt content measurement, humidimeter, binoculars, cracks gauge, optical microscope and colorimeter. 
This methodology included the classification of the techniques under analysis according to the principle they are based on: mechanical, ultrasonic, thermic, hydrodynamic, chemical, electrical or sensorial. It also included the characterisation of the techniques in terms of data collected, in-service performance assessment, anomaly detection and estimation of maintenance needs. It was concluded that these expedient techniques analysed presented a large spectrum in terms of the parameters mentioned and therefore, to a great extent, their selection depends on the inspector's main objectives. In order to give rational tools for this selection, a set of criteria was presented with which the techniques were rated. It was concluded that this rating, even though helpful, may exclude techniques which for some purposes are indispensable (eg the pull-off test). This rating could be improved either by using different weights for each criterion or by making some criteria eliminatory in certain cases.

\section{Acknowledgments}

The authors wish to thank the FCT (Foundation for Science and Technology) for the research grant supporting the PhD studies of the first author, LFC (Construction Physics Laboratory of FEUP), the Chemistry Department of IST, the Materials Group of IST especially Professor Gaspar Nero, ICIST/IST for the use of the equipment and Paulo Henriques (masters student at IST) for support during in situ inspections.

\section{References}

ASTM (2002a) C597-02 — Standard Test Method for Pulse Velocity Through Concrete, ASTM International, Philadelphia, USA.

ASTM (2002b) D2244-02 - Standard Practice for Calculation of Color Tolerances and Color Differences From Instrumentally Measured Color Coordinates, ASTM International, USA.

BCIS (2001) Life Expectancy of Buildings Components. Surveyor's Experiences of Building in Use - A Practical Guide, Building Cost Information Service, London, UK, p 164.

Branco, B. and de Brito, J. (2005) Handbook of Concrete Bridge Management, American Society of Civil Engineers, Reston, USA, p. 468.

BSI (1986) BS 8210. Guide to Building Maintenance Management, British Standards Institute, London, UK.

Bureau, Veritas (1993) Gestion Technique du Patrimoine - Réhabilitation et Maintenance, Guide Veritas du Bâtiment, 3rd edn, édition Le Moniteur, Bureau Veritas, Paris, France Vol. 4, p. 463.

Calejo, R. (1996) 'Design and diagnosis of pathologies in buildings - Maintenance and rehabilitation of buildings' (in Portuguese), paper presented at the 4th Civil Construction Meeting, Civil Construction Section, FEUP.

Campanella, C. (2003) Works of Conservation and Architectonic Restoration - Special Technical Conditions (in Portuguese), coordinated/adapted by João Mascarenhas Mateus, Municipal County of Lisbon, Lisbon, Portugal, p. 211.

CEN (2003) EN 998-1 - Methods of Test for Mortar for Masonry. Part 1: Rendering and Plastering Mortar, Comité Européen de Normalisation, Brussels, Belgium.

Flores, I. (2002) Maintenance Strategies - Elements of the Envelope of Current Buildings (in Portuguese), master's thesis, IST, Lisbon, Portugal, p. 186.

Flores-Colen, I., de Brito, J. and Freitas, V.P (2005) 'Selected aspects of rendering performance based on in-field assessment', paper presented at the Probe Conference, The Second Scottish Conference for Postgraduate Researcher of The Built and Natural Environment, Glasgow Caledonian University, Scotland, UK.

Flores-Colen, I., de Brito, J. and Freitas, V..P. (2006) 'Stains in façades rendering — Diagnosis and maintenance techniques classification', Construction and Building Materials, forthcoming. 
Flores-Colen, I. and de Brito, J (2004) 'Predictive maintenance of buildings' (in Portuguese), Construção Magazine, 2nd Trimester, 3(9): 14-20.

Hertlein, B. (1999) 'Predictive maintenance - What should be in a condition database', in Proceedings of 8th International Conference on Durability of Building Materials and Components, Institute for Research in Construction, Ottawa, Canada, pp. 1203-1212.

Hollis, M. and Gibson, C (1991) Surveying Buildings, 3rd edn, RICS Books, London, UK, p 236.

ISO (2000) ISO 15686-1. Buildings and Constructed Assets - Service Life Planning. Part 1: General Principles, International Standards Organization, Geneva, Switzerland.

ISO (2001) ISO 15686-2. Buildings and Constructed Assets - Service Life Planning. Part 2: Service Life Prediction Procedures, International Standards Organization, Geneva, Switzerland.

Morcous, G. and Lounis, Z. (2005) 'Maintenance optimisation of infrastructure networks using genetic algorithms', Automation in Construction, 14(1), 129-142.

Palmer, D. (1999) Maintenance Planning and Scheduling Handbook, McGraw-Hill, Columbus, USA.

Perret, J. (1995) Guide de la Maintenance des Bâtiments, Moniteur Référence Technique, Paris, France, $\mathrm{p} 431$.

Riley, M. and Cotgrave, A. (2005) 'The context of maintenance', in Riley, M. and Cotgrave, A. Construction Technology 3. The Technology of Refurbishment and Maintenance, Palgrave Macmillan, Basingstoke, UK, pp. 50-56.

RILEM (1980) Water Absorption Under Low Pressure. Pipe Method. Test No. II. 4, Recommandations Provisoires, Paris, France.

RILEM (1982) Characterization of the Surface Strength of Renderings by the Pendulum Ball Test, RILEM Technical Recommendation MR1-19, E \& FN Spon, London, UK.

RILEM(1997) 'Recommendation MS-D. Determination of pointing hardness by pendulum hammer, TC 127-MS: Tests for masonry', Materials and Structures, 29(192), pp. 323-324.

$\operatorname{RILEM}(2004)$ 'Recommendation MDT D.3. Determination "in situ" of the adhesive strength of rendering and plastering mortars to their substrate', Materials and Structures, 37(August-September), 488-490.

Silva, V.C. (2004) Manual of Inspections and Tests for Rehabilitation of Buildings (in Portuguese), CD-ROM, available from Grémio das Empresas de Conservação e Restauro do Património Arquitectónico (GECoRPA), Portugal.

Veiga, R. (2005) 'Behaviour of façades claddings based on mineral binders — Functional requirements and performance assessment', (in Portuguese), paper presented at the 1st National Congress of Construction Mortars, APFAC, Lisbon, Portugal, available on CD-ROM, available from Associação Portuguesa dos Fabricantes de Argamassas de Construção (APFAC), Portugal. 